\title{
The Relationship between Educational Transformational Leadership and Teacher Quality at Secondary School: Total Quality Management as Mediator
}

\author{
Mohd Rahimi A Rahman, Mohamed Yusoff Mohd Nor*, Jamalul Lail Abdul Wahab, Ashairi Suliman \\ Faculty of Education, Universiti Kebangsaan Malaysia, 43600, Bangi, Selangor Darul Ehsan, Malaysia
}

Received April 10, 2020; Revised October 26, 2020; Accepted November 1, 2020

\begin{abstract}
Cite This Paper in the following Citation Styles
(a): [1] Mohd Rahimi A Rahman, Mohamed Yusoff Mohd Nor, Jamalul Lail Abdul Wahab, Ashairi Suliman, "The Relationship between Educational Transformational Leadership and Teacher Quality at Secondary School: Total Quality Management as Mediator," Universal Journal of Educational Research, Vol. 8, No. 12, pp. 6369-6377, 2020. DOI: 10.13189/ujer.2020.081202.
\end{abstract}

(b): Mohd Rahimi A Rahman, Mohamed Yusoff Mohd Nor, Jamalul Lail Abdul Wahab, Ashairi Suliman (2020). The Relationship between Educational Transformational Leadership and Teacher Quality at Secondary School: Total Quality Management as Mediator. Universal Journal of Educational Research, 8(12), 6369-6377. DOI: 10.13189/ujer.2020.081202.

Copyright $\bigcirc 2020$ by authors, all rights reserved. Authors agree that this article remains permanently open access under the terms of the Creative Commons Attribution License 4.0 International License

\begin{abstract}
This study aims to examine the relationship between educational transformation leadership and the quality of teachers in secondary schools, as well as to identify the impact of total quality management practices on the relationship between both variables. This study used a cross-sectional survey involving 423 secondary school teachers from across Malaysia. Data were collected using questionnaires adapted from Total Quality Management Instruments, Multi-Factor Leadership Questionnaire and Malaysian Teacher Standards Instruments. This study used the Pearson Correlation inference analysis to determine the relationship between variables and SPSS Process Macro 3.0 analysis to identify mediator effects. The results show that the relationships between educational leadership and Total Quality Management practices (.768), Total Quality Management practices and teacher quality (.942), educational transformational leadership and teacher quality (.846) are all positive and significant. In addition, the Variance Accounted For (VAF) for the mediator is $64.62 \%$. Thus, it can be concluded that Total Quality Management has a partial mediator effect on the relationship between educational transformational leadership and teacher quality in secondary schools. The findings of this study can
\end{abstract}

contribute to the improvement of school management practices, specifically through the implementation of educational transformational leadership, Total Quality Management and teachers' quality. In summary, the findings suggest that educational transformational leadership and Total Quality Management can contribute to the improvement of teachers' quality.

Keywords Educational Transformational Leadership, Teacher Quality, Total Quality Management, Secondary School

\section{Introduction}

Teachers play a significant role in helping to achieve students' excellence and school effectiveness, specifically in implementing an effective education system to develop a highly educated, knowledge-driven society [1]. Teachers are among the essential component in realizing the country's educational aspiration [2]. This is especially true in today's world, where the robust development of technology has changed the field of education. In line with 
the National Philosophy of Education, teachers contribute to the government's effort to produce holistic individuals with balanced spiritual, physical and emotional growth. This is to ensure the future generation achieves personal well-being and contribute to the country's prosperity and growth [3].

Based on the above argument, having quality teachers is very important to an education system. In other words, teachers' quality ensures teachers have self-efficacy in teaching [4]. Teachers' quality can also reflect a teacher's job satisfaction [5] where high-quality teachers demonstrate high -commitment to carry out their responsibilities. They are also more eager to gain new knowledge and skills, have higher job loyalty and high willingness to perform their task and responsibilities without any coercion [1]. The presence of quality teachers who are creative, efficient, highly motivated and well-educated is one of the key elements in enhancing the effectiveness of teaching and learning in schools [6]. Thus, quality teachers play an important role in fulfilling the goals of the education system by achieving their school's goals [7]. This further demonstrates that having high-quality teachers is an important aspect in the attempt to fulfil Malaysia's aspiration to become a developed and educated country. All these aspects can be fulfilled if the teachers have excellent professional and personal qualities.

Based on the arguments above, the aspect of teacher quality needs to be considered to address issues linked to the increase in teachers' workload. It is argued that quality teachers will demonstrate the best work performance, and this could increase a school's productivity, capacity, and excellence [8]. On the other hand, as the notion of ideal teacher's quality might differ across individuals and the fact that teachers have the different responsibilities, burdens, problems, exposure and experiences [6], it is challenging to measure and quantify teacher's quality

The committee on Teachers' workload and Responsibility conducted a comprehensive study in 2007 and found that a teacher in Malaysia spends an average of 66.24 hours a week to perform duties and responsibilities as an educator [9]. This amount is greater than the average weekly work hours as recommended by the International Labour Organisation (ILO) at 45 hours a week. It was also found that on top of curriculum and co-curriculum related tasks such as teaching, lesson planning, lesson preparation, assessment, and additional classes, Malaysian teachers are often burdened also tasks related to community relations, staff development, physical development, administrative works, finance, student affairs and hostel management tasks [9].

\section{Theoretical Background}

The issue on teachers' workload has led to the implementation of quality management initiatives such as Total Quality Management (TQM), Innovative and
Creative (IC) practices, Work Quality Improvement Group (WQIG) and Quality School Management System (QSMS). In this light, while these quality management practices have been implemented in the public service to ensure effective government service delivery, the implementation of quality management is still poor at the school level [10].

Leadership is a process of influencing a group of individuals to achieve a common goal or vision [11]. On top of that, educational transformational leadership is an important aspect that shapes the culture and effectiveness of a school. It was found that effective educational leadership could positively influence job satisfaction and teachers' commitment [12]. Each principal adopts his/her style of leadership, depending on the school circumstances and direction. Studies have found that school leaders' implementation of educational transformational leadership influences teacher's attitudes and behaviours, specifically in working towards achieving the school's goals. Thus, the existing educational transformational leadership practices need to be continually improved to ensure a school's sustainability as a learning institution [13]. Studies have posited that the practices educational transformational leadership are dependent on the conditions and attitudes of teachers in the school [14]. Based on this statement, this study will identify the needs for principals' implementation of educational transformational leadership to improve the quality of teachers in secondary school

Good school quality management practices lead to school effectiveness without relying solely on the principal's leadership practices [15]. It could ensure that a school still maintains its excellence despite changes in its leadership. In this regard, teachers' quality and all aspects within the school can be systematically shaped to produce students who are excellent in every aspect [15]. Effective quality management practices will also ensure that the teachers and the school staff are able to take on their tasks and responsibilities according to the guidelines provided by the school's quality management. As a result, the teachers will work diligently to fulfil the students' learning needs.

There is still room for studying the gaps in teacher quality to address the issues and challenges discussed earlier. This could be done by adopting a more comprehensive and effective approach which incorporates educational leadership. Based on this argument, this study aims to identify the relationship between the implementation of educational transformational leadership, Total Quality Management practices and teachers' quality. In addition, this study examines the mediator role of Total Quality Management Practices in the relationship between educational transformational leadership and teachers' quality in secondary schools.

This study provides an overview of the relationship between the independent variable (educational transformational leadership), the mediating variable (total quality management) and the dependent variable (teacher 
quality). This framework is based on the extended Social Cognitive Career Theory, as developed by [16], which presents a more detailed model of individual achievement. The model was developed to understand the factors related to teachers' career development in education and vocational education [16]. The extended model also emphasises on the relationship between behaviour, environmental factor, and individual's development and achievement [16]. The main framework of this study is supported by three main models, which are Transformational Leadership Theory [17] Total Quality Management Model [18] and the Malaysian Teacher Standards [19].

Figure 1 illustrates the relationship between independent variables (educational transformational leadership), mediator variables (total quality management) and dependent variables (teacher quality).

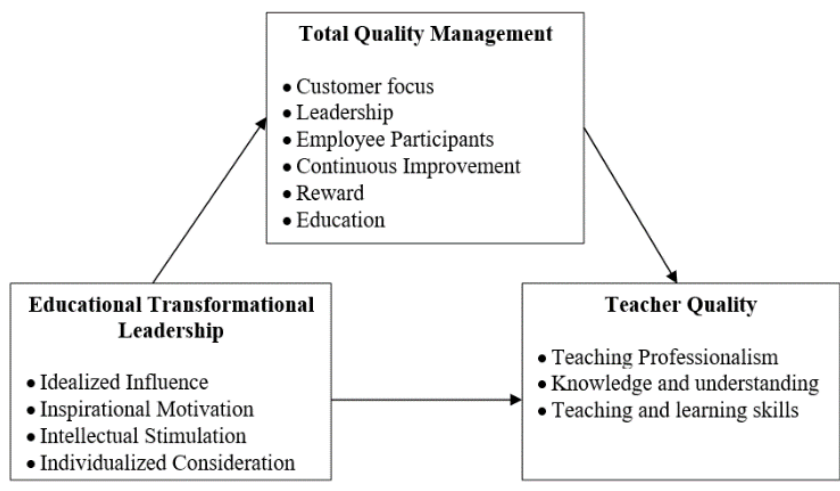

Figure 1. Relationship between Educational Transformational Leadership and Teacher Quality: Total Quality Management as Mediator

\section{Materials and Methods}

\section{Study Design}

Data for this study were collected using a cross-sectional survey method, and the data were collected only at a single time point. This study's respondents consist of secondary school teachers from across Malaysia. This study collected numerical data which were then analysed using statistical tests. This study presents a descriptive form of correlation which examines the relationship between educational transformational leadership and teachers' quality. This study describes the phenomenon by analysing the data obtained from the survey questionnaire. All information obtained were classified according to the specified aspect and quantitatively interpreted. The study also conducted statistical tests to determine the items' reliability and validity, constructing facts and identifying the relationships between variables.

\section{Sample}

The population of this study comprises teachers who are teaching national secondary schools. Teachers from national secondary schools were chosen as they have diverse responsibilities than teachers teaching in other types of schools. The number of samples was determined based on the appropriate sample size recommended by [20-21], as well as the study's design, procedure, and statistical analyses. In all, 423 teachers are involved in this study.

The respondents were chosen through the simple random sampling procedure. The simple random sampling was used to ensure that each person in the population has the same opportunity to be selected as this study's respondents. Furthermore, this approach was used to choose the states to conduct the study. Table 1 illustrates the demographic profile of the study's respondents, specifically their gender, level of education and locality of their school.

Table 1. The teachers' demographic profile

\begin{tabular}{|c|c|c|c|}
\hline Profile & Category & Frequency & $\begin{array}{c}\text { Percentage } \\
(\%)\end{array}$ \\
\hline \multirow{4}{*}{ Gender } & Male & 118 & 27.9 \\
\cline { 2 - 4 } & Female & 305 & 72.1 \\
\cline { 2 - 4 } & Total & 423 & 100 \\
\hline \multirow{3}{*}{$\begin{array}{c}\text { Level of } \\
\text { Education }\end{array}$} & Graduate & 322 & 76.1 \\
\cline { 2 - 4 } & Post-Graduate & 101 & 23.9 \\
\cline { 2 - 4 } & Total & 423 & 100 \\
\hline \multirow{3}{*}{ Locality of School } & Urban & 318 & 75.2 \\
\cline { 2 - 4 } & Rural & 105 & 24.8 \\
\cline { 2 - 4 } & Total & 423 & 100 \\
\hline
\end{tabular}

\section{Research Instrument}

The data were collected through a questionnaire. The items in the questionnaire were adapted from the Multi-Factor Leadership (MLQ) [22] Total Quality Management Instrument [23], and Malaysian Teacher Standards Instrument [19]. Prior to administering the questionnaire, its construct validity and content validity were measured to ensure it can measure the true value of the concepts in this study. The items' reliability was determined using the item correlational scale and internal consistency (Cronbach's Alpha).

The items in the questionnaire were divided four sections, demographic backgrounds (section A), educational transformation leadership (section B), Total Quality Management (section C) and teacher quality (section D), as shown in Table 2. The reliability scores of the items in sections B-D are also presented in Table 2 
Table 2. Items in the survey questionnaire

\begin{tabular}{|c|c|c|c|c|}
\hline Section & Dimension & Dimension & Total & Reliability \\
\hline \multirow{3}{*}{ A } & \multirow{3}{*}{$\begin{array}{l}\text { Demographic } \\
\text { Profile }\end{array}$} & Gender & 1 & - \\
\hline & & $\begin{array}{c}\text { Level of } \\
\text { Education }\end{array}$ & 1 & - \\
\hline & & $\begin{array}{c}\text { Locality of } \\
\text { School }\end{array}$ & 1 & - \\
\hline \multirow{4}{*}{ B } & \multirow{4}{*}{$\begin{array}{c}\text { Educational } \\
\text { Transformational } \\
\text { Leadership }\end{array}$} & Ideal Influence & 7 & .852 \\
\hline & & $\begin{array}{l}\text { Inspiration } \\
\text { Motivation }\end{array}$ & 9 & .889 \\
\hline & & $\begin{array}{l}\text { Intellectual } \\
\text { Brainstorm }\end{array}$ & 8 & .906 \\
\hline & & $\begin{array}{c}\text { Individual } \\
\text { Consideration }\end{array}$ & 10 & .876 \\
\hline \multirow{6}{*}{$\mathrm{C}$} & \multirow{6}{*}{$\begin{array}{l}\text { Total Quality } \\
\text { Management }\end{array}$} & $\begin{array}{c}\text { Customer } \\
\text { Focus } \\
\end{array}$ & 6 & .847 \\
\hline & & $\begin{array}{l}\text { Management } \\
\text { Leadership }\end{array}$ & 8 & .876 \\
\hline & & $\begin{array}{c}\text { Teachers } \\
\text { Involvement }\end{array}$ & 8 & .768 \\
\hline & & $\begin{array}{l}\text { Continuous } \\
\text { Improvement }\end{array}$ & 9 & .915 \\
\hline & & Reward & 6 & .874 \\
\hline & & Education & 6 & .879 \\
\hline \multirow{3}{*}{$\mathrm{D}$} & \multirow{3}{*}{ Teacher Quality } & $\begin{array}{c}\text { Teacher } \\
\text { Professionalism } \\
\text { Practice }\end{array}$ & 26 & .966 \\
\hline & & $\begin{array}{l}\text { Knowledge and } \\
\text { Understanding }\end{array}$ & 21 & .962 \\
\hline & & $\begin{array}{l}\text { Teaching and } \\
\text { Learning Skill }\end{array}$ & 24 & .964 \\
\hline
\end{tabular}

\section{Data Analysis}

The data were analysed through Statistical analyses, which are descriptive statistics, Pearson correlation coefficient (Pearson Product - Moment Correlation Coefficient) and mediator variable analysis (SPSS PROCESS MACRO 3.0) introduced by [24]. The data collected were first analysed using the SPSS (Statistical Package for the Social Sciences) software which was designed to analyse data and information collected statistically. Prior to a more detailed data analysis, Exploratory Data Analysis was conducted for data identification. This was followed by the Pearson Correlation Coefficient and Mediator Variables Process Macro 3.0 to examine the relationships between the variables and to answer the research objectives.

\section{Research Findings}

The result in Table 3 shows that the variables for educational transformational leadership are positively correlated with Total Quality Management $(\mathrm{r}=.768, \mathrm{n}=$ $423, \mathrm{p}=.000)$. Based on the finding, it could be observed that educational transformational leadership has a high correlation with total quality management practice.
Table 3. The correlation between educational transformational leadership and total quality management

\begin{tabular}{|c|c|c|c|}
\hline & & $\begin{array}{c}\text { Educational } \\
\text { Transformational } \\
\text { Leadership }\end{array}$ & $\begin{array}{c}\text { Total } \\
\text { Quality } \\
\text { Management }\end{array}$ \\
\hline $\begin{array}{c}\text { Educational } \\
\text { Transformational } \\
\text { Leadership }\end{array}$ & $\begin{array}{c}\text { Pearson } \\
\text { Correlation } \\
\text { Sig. } \\
\text { (2-tailed) } \\
\text { N }\end{array}$ & $\begin{array}{c}1 \\
423\end{array}$ & $\begin{array}{c}.768 * * \\
.000 \\
423\end{array}$ \\
\hline $\begin{array}{l}\text { Total Quality } \\
\text { Management }\end{array}$ & $\begin{array}{c}\text { Pearson } \\
\text { Correlation } \\
\text { Sig. } \\
\text { (2-tailed) } \\
\text { N }\end{array}$ & $\begin{array}{c}.768 * * \\
.000 \\
423\end{array}$ & $\begin{array}{c}1 \\
423\end{array}$ \\
\hline
\end{tabular}

** Significant at 0.01

Table 4. Pearson Correlation test for the relationship between educational transformational leadership and total quality management

\begin{tabular}{|c|c|c|c|}
\hline \multirow{2}{*}{} & \multicolumn{3}{|c|}{ Total Quality Management } \\
\cline { 2 - 4 } & $\begin{array}{c}\text { Sig. } \\
\text { Value }\end{array}$ & $\mathrm{r}$ & Interpretation \\
\hline Idealized Influence & .000 & .686 & $\begin{array}{c}\text { High } \\
\text { correlation }\end{array}$ \\
\hline Inspirational Motivation & .000 & .733 & $\begin{array}{c}\text { High } \\
\text { correlation }\end{array}$ \\
\hline Intellectual Stimulation & .000 & .710 & $\begin{array}{c}\text { High } \\
\text { correlation }\end{array}$ \\
\hline $\begin{array}{c}\text { Individualized } \\
\text { Consideration }\end{array}$ & .000 & .697 & $\begin{array}{c}\text { High } \\
\text { correlation }\end{array}$ \\
\hline
\end{tabular}

The results in Table 4 show that the factors of Total Quality Management recorded the correlation coefficient close to 1.0. This indicates that all educational transformational leadership domains have a positive and significant relationship with Total Quality Management. However, each domain recorded different Pearson correlation coefficients. In terms of ideal influence, the coefficient is significant at .686, which indicates a strong relationship. Similarly, 'inspirational motivation' has a correlation coefficient of .733 , which also indicates a strong relationship. Intellectual stimulus also showed a high correlation coefficient of .710 and 'individual consideration' indicate that a high correlation coefficient at 697 .

Table 5. Pearson Correlation of the relationship between TQM and teacher's quality

\begin{tabular}{|c|c|c|c|}
\hline \multirow{2}{*}{ Customer Focus } & \multicolumn{3}{|c|}{ Teacher Quality } \\
\cline { 2 - 4 } & Sig. Value & $\mathrm{r}$ & Interpretation \\
\hline Leadership & .000 & .766 & $\begin{array}{c}\text { High } \\
\text { correlation }\end{array}$ \\
\hline Employee Participant & .000 & .815 & $\begin{array}{c}\text { High } \\
\text { correlation }\end{array}$ \\
\hline Continuous Improvement & .000 & .830 & $\begin{array}{c}\text { High } \\
\text { correlation }\end{array}$ \\
\hline Reward & .000 & .636 & $\begin{array}{c}\text { High } \\
\text { correlation } \\
\text { correlation }\end{array}$ \\
\hline Education & .000 & .814 & $\begin{array}{c}\text { High } \\
\text { correlation }\end{array}$ \\
\hline
\end{tabular}


Table 5 shows that all factors related to Total quality management practices have a positive and significant relationship. All total quality management domains showed positive and significant relationships to teacher quality. However, each factor recorded different Pearson correlation coefficient. The factor of 'continuous improvement' showed the highest correlation coefficient at .830 , followed by 'administrative leadership' with a correlation coefficient of .815. This is followed by education which scored a high correlation coefficient at .814 .

In terms of students' focus, the coefficient of significance is at .766, followed by teachers' involvement scored the coefficient of .675 , and rewards with the correlation coefficient at .636 . The results show that all factors have a strong relationship with teachers' quality. In this light, the correlation between Total Quality Management Practices and teacher quality is high at .942.

Table 6. Correlation test between TQM and teacher quality

\begin{tabular}{|c|c|c|c|}
\hline \multicolumn{2}{|c|}{} & $\begin{array}{c}\text { Total Quality } \\
\text { Management }\end{array}$ & $\begin{array}{c}\text { Teacher } \\
\text { Quality }\end{array}$ \\
\hline $\begin{array}{c}\text { Total Quality } \\
\text { Management }\end{array}$ & $\begin{array}{c}\text { Pearson } \\
\text { Correlation } \\
\text { Sig. (2-tailed) } \\
\text { N }\end{array}$ & 1 & $\begin{array}{c}.942 * * \\
.000 \\
423\end{array}$ \\
\hline Teacher & $\begin{array}{c}\text { Pearson } \\
\text { Quality }\end{array}$ & $\begin{array}{c}\text { Correlation } \\
\text { Sig. (2-tailed) } \\
\text { N }\end{array}$ & $\begin{array}{c}.942^{* *} \\
.000\end{array}$ \\
423 & 1 \\
\hline
\end{tabular}

* Significant at sig. level 0.01

Table 6 shows that all variables for Total Quality Management are positively and significantly linked to teachers' quality with the correlation of .942 .

The results in Table 7 show that all variables for transformational leadership are significantly and positively correlated to teachers' quality (.846).
Table 7. Correlational analysis between educational transformational leadership and teachers' quality

\begin{tabular}{|c|c|c|c|}
\hline \multicolumn{2}{|c|}{} & $\begin{array}{c}\text { Educational } \\
\text { Transformational } \\
\text { Leadership }\end{array}$ & $\begin{array}{c}\text { Teachers } \\
\text { Quality }\end{array}$ \\
\hline $\begin{array}{c}\text { Educational } \\
\text { Transformational } \\
\text { Leadership }\end{array}$ & $\begin{array}{c}\text { Pearson } \\
\text { Correlation } \\
\text { Sig. } \\
\text { (2-tailed) } \\
\mathrm{N}\end{array}$ & 1 & $.846^{* *}$ \\
\hline Teachers Quality & $\begin{array}{c}\text { Pearson } \\
\text { Correlation } \\
\text { Sig. } \\
(2-\text { tailed } \\
\mathrm{N}\end{array}$ & $.846^{* *}$ & .000 \\
& \multicolumn{2}{|c}{} & 423 \\
\hline
\end{tabular}

** Significant at sig 0.01

Table 8. Pearson correlation of the relationship between transformational leadership and teacher quality

\begin{tabular}{|c|c|c|c|}
\hline \multirow{2}{*}{} & \multicolumn{3}{|c|}{ Teachers Quality } \\
\cline { 2 - 4 } & $\begin{array}{c}\text { Sig. } \\
\text { Value }\end{array}$ & $\mathrm{r}$ & Interpretation \\
\hline Idealized Influence & .000 & .768 & $\begin{array}{c}\text { High } \\
\text { correlation }\end{array}$ \\
\hline Inspirational Motivation & .000 & .787 & $\begin{array}{c}\text { High } \\
\text { correlation }\end{array}$ \\
\hline Intellectual Stimulation & .000 & .780 & $\begin{array}{c}\text { High } \\
\text { correlation }\end{array}$ \\
\hline Individualized Consideration & .000 & .782 & $\begin{array}{c}\text { High } \\
\text { correlation }\end{array}$ \\
\hline
\end{tabular}

As shown in Table 8, all transformational leadership domains have a positive and significant relationship with teachers' quality. However, each domain recorded different Pearson correlation coefficients. The domain 'inspirational motivation' showed the highest correlation coefficient at .787 , followed by individual consideration at .782, 'intellectual stimulus' at .780, and ideal influence at .768. All of which indicate a strong relationship with teachers' quality.

Table 9. SPSS Macro Process 3.0 analysis on the mediator role of total quality management in the relationship between educational transformational leadership and teachers' quality at secondary school

\begin{tabular}{|c|c|c|c|c|c|}
\hline Path & $\begin{array}{c}\text { Unstandardised } \\
\text { Coefficients (B) }\end{array}$ & SE. & P (two-tailed) & \multicolumn{2}{|c|}{$95 \%$ Confidence Interval (CI) } \\
\cline { 4 - 6 } & & & & Lower Level & Upper Level \\
\hline $\begin{array}{c}\text { Total effect } \\
\left(\begin{array}{c}\text { (without mediator path c) } \\
\text { ETL } \rightarrow \text { TQ }\end{array}\right.\end{array}$ & .7445 & .0229 & .0000 & .6996 & .7894 \\
\hline $\begin{array}{c}\text { Direct effect } \\
\left(\begin{array}{c}\text { with mediator path c') } \\
\text { ETL } \rightarrow \text { TQ }\end{array}\right.\end{array}$ & .2634 & .0185 & .0000 & .2272 & .2997 \\
\hline Indirect effect & .7969 & .0324 & .0000 & .7331 & .8606 \\
\hline ETL $\rightarrow$ TQM (path a) & .6037 & .0178 & .0000 & .5687 & .6386 \\
\hline TQM $\rightarrow$ TQ (path b) & .4811 & .0006 & .0000 & .4169 & .5496 \\
\hline ETL $\rightarrow$ TQM $\rightarrow$ TQ (ab) & & & & & \\
\hline
\end{tabular}


Table 9 shows the mediator role of total quality management in the relationship between educational transformational leadership and teachers' quality. It was found that the p-value for Total Quality Management is $p$ $=.000$, which is smaller than the significant value $(p<.05)$. The result shows that educational transformational leadership can influence teachers' quality. The overall effect without mediator path from educational transformational leadership to teacher quality indicates a Beta value of .7985 , which means that Total Quality Management can influence teachers' quality by 79.85 per cent.

It was also observed that there is a positive link between educational transformational leadership and the mediating variables, namely Total Quality Management, which represents a path with Beta $=.7969$ and $\mathrm{p}$-value of .000 . These values indicate that Total Quality Management can influence transformational leadership by 79.69 per cent. Regarding the mediator role of total quality management on teacher quality, the result shows that the beta value of transformational leadership on teacher quality is .6037 and $\mathrm{p}=.000$. This result means that route $\mathrm{b}$ has a significant and positive relation effect. Here, a one per cent change in educational transformational leadership will improve teachers' quality by 60.37 per cent.

Another finding is that there is a direct relationship between educational transformational leadership and teachers' quality, with the direct effect of intermediate c at.2634 while the indirect relationship with transformational leadership is .4811. The results of this analysis indicate that Total Quality Management has a positive and significant moderator effect in the relationship between educational transformational leadership and teacher quality.

The mediator effect can be calculated using the Variance Accounted For (VAF) index, as follows:

$=\mathrm{ab} /\left(\mathrm{c}^{\prime}+\mathrm{ab}\right)$

$=.7969(.6037) /(.2634+.4811)$

$=.4811 / .7445$

$=.6462$

As the VAF for indirect effects (mediator effect) is .6462, Total Quality Management has a $64.62 \%$ effect on the relationship between educational transformational leadership and teacher quality. Thus, it can be concluded that Total Quality Management has a partial mediator effect on the relationship between educational transformational leadership and teacher quality.
Figure 2 illustrates the direct and indirect relationship between the independent, dependent variables and the mediator variable.

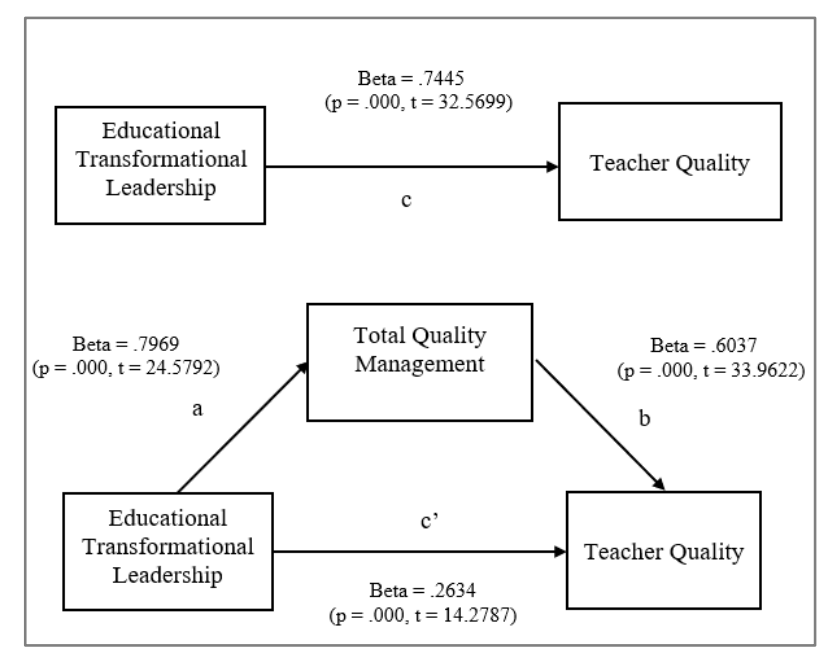

Figure 2. The mediator role of total quality management in the relationship between educational transformational leadership and teacher quality

\section{Discussion}

The data analysis revealed four significant findings. First, educational transformational leadership has a high correlation with Total Quality Management. This finding is supported by [25 - 27], as well as the findings of [28], which showed that educational transformational leadership has a significant relationship with Total Quality Management. This finding indicates that the implementation of Total Quality Management can improve transformational leadership among school principals, particularly in providing rewards and recognition to teachers.

The next significant finding shows that Total Quality Management has a high correlation with teachers' quality. The findings of this study support the findings of previous studies [29-31]. These studies demonstrated how Total Quality Management could improve teachers' quality. In addition, the findings show that reward and recognition are the factors with the strongest relationship with teaches' quality, as shown in [37-38]. The finding shows that the implementation Total Quality Management could improve teachers' quality and schools' effectiveness. Therefore, each factor in the Total Quality Management practices plays an important role in shaping the quality of teachers. 
The next significant finding is that transformational leadership has a positive and strong correlation with teacher quality. This finding is in line with studies conducted by [28 - 34] which showed the impact of educational transformational leadership relationship to teachers' quality. In this regard, transformational leadership in schools can positively influence teachers' attitude and behaviour, as well as improving teachers' quality. School leaders have been found to exude charisma, provide motivation and inspiration, encourage intellectual engagement, and execute suitable professional judgments which influenced teachers' quality.

The final finding is that Total Quality Management has a mediator effect in the relationship between educational transformational leadership and teachers' quality. Thus, the direct implementation of transformational educational leadership could improve the quality of teachers, albeit at a lower rate. This study found that the principals' implementation of Total Quality Management in secondary school could enhance the quality of teachers. Based on this evidence, principals need to implement educational transformational leadership and total quality management to change teachers' attitudes and behaviours in schools and subsequently, improves teachers' quality. In this regard, a high performing school relies on the competency of the school's work culture in managing change $[15,41]$.

\section{Summary and Implications}

The findings of this study could help increase the current understanding and knowledge of educational transformational leadership, Total Quality Management and teachers' quality. In summary, the findings suggest that educational transformational leadership and total quality management can contribute to improving teachers' quality. Teachers who gain support through a principal's implementation of transformational leadership will show increased professionalism, knowledge and understanding as well as a higher ability to facilitate teaching and learning.

This study has several implications to schools. This study's finding shows the need to find the right approach to encourage teachers to involve actively in school activities and compete with each other. This is because higher teachers' involvement will improve the teachers' quality and subsequently, the quality of the school. Therefore, the Ministry of Education should strive to implement Total Quality Management to ensure the continuous improvement of teachers' quality. More courses and workshops on Total Quality Management could be conducted to educate teachers on the importance of these practices in strengthening teachers' quality.

Moreover, to fulfil the country's aspiration to become a developed nation, there is a need for continuous improvement in the quality of teachers, in line with the goals set out in the Malaysian Education Development Plan 2013-2025. Therefore, the findings of this study can contribute to improving school management practices, specifically in the implementation of educational transformational leadership, Total Quality Management and teachers' quality. This study could become a source of information for school management to help them develop more detailed plans to implement educational transformational leadership, total quality management and improve teacher quality. The results of this study also provide useful inputs for all parties in identifying the role of total quality management in the 21 st century education system.

This study is not without its limitations. One of the limitations is that this study only examined the aspects related to educational transformational leadership, Total Quality Management and quality of teachers in national secondary schools. Therefore, future studies could further elaborate and expand this study by involving teachers and administrators from other types of school, such as boarding schools, religious schools and high performing schools.

Based on this study's findings, it could be concluded that educational transformational leadership and Total Quality Management can contribute to the improvement of teachers' quality.

\section{REFERENCES}

[1] Ministry of Education Malaysia. Pelan Induk Pembangunan Profesionalisme Keguruan (PIPPK). Ministry of Education Malaysia, 1-53, 2016.

[2] Talib, F. A., Mansor, A. N. \& Surat, S. Relationship Between Headmaster Transformational Leadership Practice and Teachers' Job Satisfaction in Kuala Langat, International Journal of Education, Psychology and Counselling, 4, 27, $63-75,2019$.

[3] Nordin, A. B. \& Othman, I. Falsafah Pendidikan dan Kurikulum, Quantum Books, Tanjung Malim, 2008.

[4] Nilsen, Trude \& Gustafsson. Teacher Quality, Instructional Quality and Student Outcomes, Springer International Publishing, New York, 2016.

[5] Yahya, Azizah \& Yaakob. Pembentukan dan peningkatan kualiti guru di Malaysia: Siri Monograf Pendidikan, Universiti Utara Malaysia Press, Sintok, 2014.

[6] Mau, W. J., Ellsworth, R. \& Hawley, D. Job satisfaction and career persistence of beginning teachers, The International Journal of Educational Management, 22, 1, 48-61, 2004.

[7] Shahril, M. Amalan pengajaran guru yang berkesan: Kajian di beberapa sekolah menengah di Malaysia, Jurnal Fakulti Pendidikan Universiti Malaya, 1-14, 2005.

[8] Ishak. R \& Rusman. S. N. F. Prestasi Kerja Guru dan Hubungannya dengan Faktor Beban Tugas, Persekitaran Kerja dan Personal: Kajian Kes di Sebuah Sekolah di Sabah, 
Jurnal Kepimpinan Pendidikan, Bil 5, Isu 1, 2018.

[9] Ministry of Education Malaysia. KPM. Pekeliling kurang tugas guru 2012, Ministry of Education, 1-22, 2007.

[10] Rahim, A., Rahman, A., \& Daud, K. Hubungan antara sistem pengurusan sekolah kualiti (SPSK) dengan kualiti dan produktiviti guru di sekolah rendah daerah Johor Bahru. Masters Dissertation, Universiti Teknologi Malaysia, 2012.

[11] Alnawasreh, R. I., Nor, M. Y. M. \& Suliman, A. Factors Affecting Malaysian International High School Students' Performance: The Moderating Effect of Transformational Leadership, Humanities and Social Sciences Reviews, 7, 5, $1262-1271,2019$.

[12] Wahab, J., Fuad, C. Ismail, H. \& Majid, S. Headmasters' Transformational Leadership and Their Relationship with Teachers' job Satisfaction and Teachers' Commitments, International Education Studies, 7, 40 - 48, 2014.

[13] Izham, Mohd \& Hamzah, MI \& Mat, Fuziah \& Nordin, Norazah \& Rahman, Saemah. School as Learning Organization: The Role of Principal's Transformational Leadership in Promoting Teacher Engagement, World Applied Sciences Journal, 14, 2011.

[14] Bass \& Bass. The Bass handbook of leadership: Theory, research, and managerial applications (4th ed.), Free Press, New York, 2008.

[15] Davies, B. \& Burnham, J. W. Reengineering and total quality in school, Pearson Education, United Kingdom, 2010 .

[16] Lent, R. W. \& Brown, S. D. Integrating person and situation perspectives on work satisfaction: A social-cognitive view, Journal of Vocational Behavior, 69, 2, 236-247, 2006.

[17] Bass, B. M. Leadership and performance beyond expectations, Free Press, New York, 1985.

[18] Oakland, J. Total Quality Management and Operational Excellence, Routledge, London, 2014.

[19] Ministry of Education Malaysia. Malaysian Teachers Standard (SGM), Ministry of Education, 2008.

[20] Krejcie, R. V \& Morgan, D. W. Determining Sample Size for Research Activities Robert, Educational and Psychological Measurement 38(1): 607-610, 1970.

[21] Cohen, J. A power primer, Psychological Bulletin, 112 (1): 155-159, 1992.

[22] Avolio, B. J., \& Bass, B. M. Multifactor leadership questionnaire, manual and sampler set (3rd ed.), Redwood City, Mind Garden, 2004.

[23] Zhang, Z., Waszink, A. \& Wijngaard, J. An instrument for measuring TQM implementation for Chinese manufacturing companies, International Journal of Quality \& Reliability Management, Vol. 17, No. 7, 730-55, 2000.

[24] Hayes, A. F. Introduction to Mediation, Moderation, and Conditional Process Analysis, The Guilford Press, New York, 2013.

[25] Boberg, J. E. \& Bourgeois, S. J. The effects of integrated transformational leadership on achievement, Journal of Educational Administration, Vol. 54, Issue 3, 357-374,
2016.

[26] Hoque, K. E., Alam, G. M. \& Abdullah, A. G. K. Impact of teachers' professional development on school improvement-an analysis at Bangladesh standpoint, Asia Pacific Education Review, 12, 3, 337-348, 2011.

[27] Rahman, F., Nabi Bux, J., Akhter, Y., Saeed Ul Hasan, C. \& Ajmal, M. Relationship Between Training Of Teachers And Effectiveness Teaching, International Journal of Business and Social Science, 2, 150-160, 2011.

[28] Suarman, S. Teaching Quality and Students Satisfaction: The Intermediatory Role of Relationship between Lecturers and Students of the Higher Learning Institutes, Mediterranean Journal of Social Sciences, 6, 2, 626-632, 2015.

[29] Kirunda, H. K. Performance-Based Rewards and the Performance of Teachers in Private Secondary Schools in Kampala District, Journal of Business Strategies, 7, 5, 132$145,2004$.

[30] Ehigie, B. O. \& Akpan, R C. Roles of perceived leadership styles and rewards in the practice of total quality management, Leadership \& Organization Development Journal, Vol. 25, Issue 1, 24-40, 2004.

[31] Yu, H., Leithwood, K. \& Jantzi, D. The effects of transformational leadership on teachers' commitment to change in Hong Kong, Journal of Educational Administration, Vol. 40, No. 4, 368-389, 2002.

[32] Geijsel F., Sleegers P., Leithwood K., \& Jantzi D. Transformational leadership effects on teachers' commitment and effort toward school reform, Journal of Educational Administration, Vol. 41, Issue 3, 228-256, 2006.

[33] Eyal O. \& Roth G. Principals' leadership and teachers' motivation: Self-determination theory analysis, Journal of Educational Administration, Vol. 49, Issue 3, 256-275, 2011.

[34] Menon, M. E. The relationship between transformational leadership, perceived leader effectiveness and teachers' job satisfaction, Journal of Educational Administration, Vol. 52, Issue 4, 509-528, 2014.

[35] Pounder, J. Quality teaching through transformational classroom leadership, Quality Assurance in Education, Vol. 22, Issue 3, 273-285, 2014.

[36] Rao, M. S. Transformational leadership - an academic case study, Industrial and Commercial Training, Vol. 46, Issue 3, 150-154, 2014.

[37] Berson, Y., \& Linton, J. An examination of the relationships between leadership style, quality, and employee satisfaction in $\mathrm{R} \& \mathrm{D}$ versus administrative environments, $\mathrm{R}$ and $\mathrm{D}$ Management, 35, 1, 51- 60, 2005.

[38] Young, S. C. \& Joo, Y. J. The verification of effective leadership style for TQM: A comparative study between USA-based firms and China-based firms, International Journal of Quality \& Reliability Management, Vol. 31, Issue 7, 822-840, 2014.

[39] Kumar V. \& Sharma R. R. K. Relating management problem-solving styles of leaders to TQM focus: an empirical study, The TQM Journal, Vol. 29, Issue 2, 
218-239, 2017.

[40] Dee, T. S. \& Wyckoff, J. H. Incentives, Selection, and Teacher Performance: Evidence from Impact, Journal of Policy Analysis and Management, 34, 2, 267-297, 2015.
[41] Nor. M. Y. M., Mansor, A. N. \& Suliman, A. The Practice of School Based Management: Special Reference to Malaysian Clusters Schools and UK Autonomous Schools, Journal of Advance Research in Dynamical and Control Systems, 10, 2 , $1618-1626,2018$. 